\title{
Studies on Genetic Variability, Heritability and Genetic Advance for Yield and Yield Attributing Characters in Cluster Bean [Cyamopsis tetragonoloba (L.) Taub.]
}

\author{
G. Rishitha*, R. Rajya Lakshmi, K. Uma Jyothi and K. Uma Krishna \\ Department of Vegetable Science, College of Horticulture Venkataramannagudem, \\ Dr.YSRHU, AP, India \\ *Corresponding author
}

Keywords

Cluster bean, Variability, GCV, PCV, Heritability, Genetic advance

Article Info

Accepted:

12 July 2019

Available Online:

10 August 2019

\section{A B S T R A C T}

Twenty six genotypes of cluster bean [Cyamopsis tetragonoloba (L.) Taub] were evaluated to estimate variability, broad sense heritability and genetic advance for pod yield and related attributes, during Rabi 2017. High estimates of GCV and PCV were recorded for number of branches per plant, plant spread at final harvest, fresh pod yield per plant, pod yield per plot, pod yield per hectare, number of pods per cluster, TSS and protein. High heritability coupled with high genetic advance as per cent of mean was observed for number of branches per plant, plant spread, number of pods per cluster, leaf length, leaf width, leaf area, days taken to pod maturity, pod length, TSS, protein $\%$, fibre $\%$ and moisture $\%$. High heritability with low genetic advance was observed for days to 50\% flowering and days to first harvest. The results of the present investigation suggests that number of branches per plant, plant spread, number of pods per cluster, leaf length, leaf width, leaf area, days taken to pod maturity, pod length, TSS, protein $\%$, fibre $\%$ and moisture $\%$ had predominance of additive gene action and hence selection is more effective.

\section{Introduction}

Cluster bean [Cyamopsis tetragonoloba (L.) Taub.] belongs to the family Leguminosae with diploid chromosome number $2 n=2 x=14$ and it is commonly known as guar, chavli kayi, goru chikkudu, guari, Khutti etc.

Being a short duration crop, it holds immense potential to generate better economic returns to the growers from marginal land holdings with a huge production.
Cluster bean is rich in dietary fibre, potassium and folate which protect the heart from various cardiovascular complications. It is a reservoir of different amino acids including glutamine, arginine, aspartic acid and leucine.

Iron and calcium present in the cluster bean fills up the deficiencies and helps in strengthening the bones. It also works as a good laxative, stimulating bowel movement, improving digestive system and help in flushing out unwanted chemicals. 
Seeds of cluster bean have a large endosperm when compared to other legumes, and contains galactomannan type of gum, which forms viscous gel and has diversified industrial applications viz., paper, food, cosmetics, mining, petroleum, well drilling, pharmaceuticals etc (Pathak et al., 2009). It is also used as a thickener in ice creams, bakery mixes and salad dressings and as a foam stabilizer in beer and in adhesives for postage stamps.

Cluster bean has wide scope for improvement through systematic and planned breeding programme. The yield potential of the crop is mainly determined by the genetic makeup, but is highly influenced by the environmental factors. Therefore, an attempt was made to study the mean performance of quantitative and qualitative traits, variance, heritability and genetic advance of different characters. Studies on genetic variability for yield and yield component characters are a pre requisite. Since, phenotypic variability is highly influenced by the environment; it does not give a real picture of the potential genotypic variability. Hence, knowledge about heritability and genetic advance on yield and yield contributing characters are necessary for the crop improvement through selection.

\section{Materials and Methods}

The material consisted of 26 phenotypically superior and diverse genotypes including 2 checks (Pusa Navbahar and Local Variety) of cluster bean from NBPGR sub centre Jodhpur (Table 1). All these genotypes were evaluated in Randomised complete block design with two replications at Mango research station, DR.YSR horticultural University, Venkataramannagudem, during Rabi 2017. Each plot comprised of two rows of 4 meter length, the spacing between row to row and plant to plant was $30 \mathrm{~cm}$ and $10 \mathrm{~cm}$, respectively. Normal and uniform cultural operations were followed to raise a good crop. The observations were recorded on the basis of five randomly selected plants from each replication for 23 characters viz., germination percentage, leaf length, leaf width, leaf area, plant height at final harvest, plant spread at final harvest, pod length, pod girth, number of pods per cluster, number of clusters per plant, number of pods per plant, number of seeds per pod, pod yield per hectare, TSS, protein $\%$, fibre $\%$ and moisture $\%$ while days to $50 \%$ flowering, days taken to pod maturity, days to first harvest were recorded on plot basis. The mean data were subjected to statistical analysis for estimating variability, phenotypic and genotypic co-efficient of variation using formula suggested by Burton (1952), heritability (h2) according to Lush (1940) and genetic advance over mean was predicted by using the formula suggested by Johnson et al., (1955).

\section{Results and Discussion}

Analysis of variance revealed significant difference among the genotypes for all the characters studied, indicating the significant amount of variability (Table 1). The general mean, range, phenotypic and genotypic variance is presented in (Table 2). Information on the relative amount of variation can be obtained by correlating co-efficients of phenotypic and genotypic variation of every character investigated. It was observed that phenotypic variance was higher than genotypic variance for all the characters studied.

Among the characters studied, high PCV and GCV were observed for characters like number of branches per plant, plant spread at final harvest, fresh pod yield per plant, pod yield per plot, pod yield per hectare, number of pods per cluster, TSS and protein indicating high variability available in the germplasm for these characters for further improvement. 
The magnitude of phenotypic coefficient of variation was higher than corresponding genotypic coefficient of variation indicating the influence of environmental factors in their expression. These results are similar to those of Hanchinamani, (2004), Dwivedi, (2009) and Malaghan, (2012) which indicate that greater the genetic variability among the parents, more are the chances of further improvement.

PCV ranged from 5.14 (days to first harvest) to 36.45 (Fresh pod yield per plant) and GCV ranged from 4.84 (days to first harvest) to 32.06 (number of branches per plant).

High heritability coupled with high genetic advance as per cent of mean was observed for the traits number of branches per plant, plant spread, number of pods per cluster, leaf length, leaf width, leaf area, days taken to pod maturity, pod length, TSS, Protein \%, fibre \% and moisture \% which indicated the preponderance of additive gene action governing the inheritance of this character and offers the best possibility of improvement of this trait through simple selection procedures. Similar findings were reported by Kumar and Ram (2015), Patil (2014), Bhatkodle et al., (2014), Muthuselvi and Shanthi (2013), Rai et al., (2012), Saini et al.,(2010), Sabarish (2010), Prakash et al., (2009), Anandhi and Oommen (2007), Saini et al.,(2004), Singh et al., (2004), Hanchinamani (2004), Singh et al., (2001), Choudhary and Joshi(1996) and Mital and Thomas (1969) in cluster bean, Rai et al., (2004) and Singh et al., (2000) in French bean.

Table.1 Analysis of variance for different traits in 26 genotypes of cluster bean

\begin{tabular}{|c|c|c|c|c|}
\hline \multirow[t]{2}{*}{ S. No. } & \multirow[t]{2}{*}{ Character } & \multicolumn{3}{|c|}{ Mean sum of squares } \\
\hline & & Replications df $=1$ & Treatments df $=25$ & Error $\mathbf{d f}=\mathbf{2 5}$ \\
\hline 1 & Germination \% & 7.72 & $168.16^{* *}$ & 64.27 \\
\hline 2 & Leaf length $(\mathrm{cm})$ & 0.014 & $2.15 * *$ & 0.05 \\
\hline 3 & Leaf width $(\mathrm{cm})$ & 0.0012 & $0.73 * *$ & 0.02 \\
\hline 4 & Leaf area $\left(\mathrm{cm}^{2}\right)$ & 1891.25 & $17987.93 * *$ & 494.97 \\
\hline 5 & Days to $50 \%$ flowering & 0.48 & $3.59 * *$ & 0.28 \\
\hline 6 & Days taken to Pod maturity & 1.92 & $4.35 * *$ & 0.72 \\
\hline 7 & Days to first harvest & 0.30 & $7.59 * *$ & 0.46 \\
\hline 8 & Plant height at final harvest $(\mathrm{cm})$ & 367.55 & $295.22 *$ & 127.02 \\
\hline 9 & Plant spread at final harvest $(\mathrm{cm})$ & 342.25 & $732.62 * *$ & 101.15 \\
\hline 10 & Number of branches/ plant & 0.64 & $9.83 * *$ & 0.82 \\
\hline 11 & Pod length $(\mathrm{cm})$ & 1.92 & $5.49 * *$ & 0.54 \\
\hline 12 & Pod girth (mm) & 1.85 & $1.33 * *$ & 0.48 \\
\hline 13 & Number of pods/cluster & 0.22 & $6.31 * *$ & 0.49 \\
\hline 14 & Number of clusters/plant & 5.27 & $8.37 * *$ & 1.30 \\
\hline 15 & Number of pods/plant & 77.49 & $715.50 * *$ & 137.66 \\
\hline 16 & Number of seeds/pod & 0.22 & $0.52 * *$ & 0.05 \\
\hline 17 & Fresh pod yield/plant (g) & 41.28 & $5112.81 * *$ & 149.77 \\
\hline 18 & Pod yield/plot $(\mathrm{Kg})$ & 1.98 & $3.17 * *$ & 0.63 \\
\hline 19 & Pod yield/ha (q) & 3380.20 & $5369.63 * *$ & 858.2 \\
\hline 20 & TSS ( ${ }^{\circ}$ Brix) & 0.0156 & $0.39 * *$ & 0.62 \\
\hline 21 & Protein \% & 1.80 & $74.71 * *$ & 1.77 \\
\hline 22 & Fibre \% & 0.10 & $1.10 * *$ & 0.06 \\
\hline 23 & Moisture \% & 12.96 & $239.69 * *$ & 6.81 \\
\hline
\end{tabular}


Table.2 Estimates of variability and genetic parameters for yield and its attributes in cluster bean

\begin{tabular}{|l|c|c|c|c|}
\hline \multicolumn{1}{|c|}{ CHARACTER } & PCV \% & GCV \% & $\begin{array}{c}\text { Heritability } \\
\text { \% }\end{array}$ & $\begin{array}{c}\text { GAM at } \\
\mathbf{5 \%}\end{array}$ \\
\hline Germination \% & & & 44.69 & 11.65 \\
\hline Leaf length (cm) & 12.66 & 8.46 & 95.45 & 27.33 \\
\hline Leaf width(cm) & 13.98 & 13.62 & 92.10 & 25.79 \\
\hline Leaf area(cm $)$ & 13.35 & 12.93 & 94.64 & 40.79 \\
\hline Days to 50\% flowering & 20.92 & 20.35 & 85.56 & 9.50 \\
\hline Days taken to Pod maturity & 5.39 & 4.99 & 71.65 & 20.35 \\
\hline Days to first harvest & 13.81 & 11.68 & 88.58 & 9.37 \\
\hline Plant height at final harvest (cm) & 5.14 & 4.84 & 39.82 & 14.87 \\
\hline Plant spread at final harvest $(\mathbf{c m})$ & 18.12 & 11.44 & 75.73 & 52.18 \\
\hline Number of branches/ plant & 33.44 & 29.10 & 84.43 & 60.19 \\
\hline Pod length (cm) & 22.84 & 18.85 & 68.19 & 32.06 \\
\hline Pod girth (mm) & 11.37 & 8.88 & 60.24 & 14.22 \\
\hline Number of pods/cluster & 27.04 & 25.01 & 85.58 & 47.65 \\
\hline Number of clusters/plant & 15.20 & 11.61 & 58.33 & 18.26 \\
\hline Number of pods/plant & 24.48 & 16.44 & 45.07 & 22.73 \\
\hline Number of seeds/pod & 7.62 & 6.68 & 76.66 & 12.04 \\
\hline Fresh pod yield/plant (g) & 36.45 & 27.58 & 57.22 & 42.97 \\
\hline Pod yield/plot (kg) & 33.38 & 25.19 & 56.93 & 39.14 \\
\hline Pod yield/ha (q) & 33.38 & 25.19 & 56.93 & 39.14 \\
\hline TSS ( Brix) & 22.88 & 21.31 & 85.71 & 40.89 \\
\hline Protein percent (\%) & 24.41 & 23.84 & 95.37 & 47.96 \\
\hline Fibre percent (\%) & 15.22 & 14.34 & 88.13 & 27.83 \\
\hline Moisture percent (\%) $(20.66$ & 20.08 & 94.32 & 40.21 \\
\hline
\end{tabular}

High heritability with moderate genetic advance as per cent of mean is observed for pod girth and number of seeds per pod. This indicates the influence of non-additive gene action and considerable influence of environment on the expression of these traits. These traits could be exploited through manifestation of dominance and epistatic components through heterosis breeding.

Moderate heritability coupled with moderate genetic advance as per cent of mean was observed for the traits like germination percentage, plant height at final harvest, and number of clusters per plant similar findings was reported by Patil (2014) and Revathi et al., (2017). High heritability with low genetic advance as per cent of mean was observed for the traits like days to $50 \%$ flowering and days to first harvest. It is an indicative of nonadditive gene action and high heritability is being exhibited due to favourable influence of environment rather than genotype and selection for such traits may not be effective. These results are similar with findings of Anandhi and Oommen (2007) in cluster bean.

Prevalence of high degree of additive components of genetic variance, high estimates of heritability coupled with high GAM and presence of high GCV and PCV for the characters, number of branches per plant, 
plant spread at final harvest, fresh pod yield per plant, pod yield per plot, pod yield per hectare, number of pods per cluster, TSS and protein indicated additive gene action hence, higher degree of genetic improvement for these traits can be achieved through selection using the existing germplasm stock.

\section{References}

Anandhi, K. and Oommen, S. K. 2007. Variability and heritability of yield and related characters in cluster bean, Legume Research. 30 (4): 287-89.

Bhatkodle, G. S, Indiresh, K. M. and Muralidhara, M. S. 2014. Assessment of genetic variability for yield and quality attributes in vegetable type cluster bean (Cyamopsis tetragonoloba Linn. Taub.). Indian Horticulture Journal. 4(3): 141143.

Burton, G. W. and Devane, E. H. 1952. Estimating heritability in tall fescue (Festuca arundinaceae) from replicated clonal material. Agronomy Journal. 45: 478-481.

Choudhary, B. R. and Joshi, P. 1996. Selection indices in cluster bean [Cyamopsis tetragonoloba (L.) Taub.]. Indian Journal of Genetics. 56 (3): 27880.

Dwivedi, N. K. 2009. Evaluation of vegetable guar [Cyamopsis tetragonoloba (L.) Taub.] germplasm. Journal of Arid Legumes. 6(1): 17-19.

Hanchimani, N, Patil, G, Ravindra Mulge, M. P. and Madalageri, M. B. 2004. Genetic variability studies for seed yield and quality characters in cluster bean. National symposium on arid legumes for sustainable agriculture and trade. I7, pp.5.

Johnson, H. W, Robinson, H. F. and Comstock, R. E. 1955. Estimates of genetic and environmental variability of Soybean. Agronomy Journal. 47: 314-
18.

Kumar, V. and Ram, R. B. 2015. Genetic variability, Correlation and Path analysis for Yield and Yield attributing Traits in Cluster bean [Cyamopsis tetragonoloba (L.) Taub.] Genotypes. International Journal of Pure and Applied Bioscience. 3 (1): 143-49.

Lush, J.L.1940. Intra-sire Correlation on Regression Off-spring on Dams as a Method of Estimating Heritability of Characters. Proceedings of American Society of Animal Production. 33: 292301.

Malaghan, S. N. 2012. Genetic variability and divergence studies in cluster bean (Cyamopsis tetragonoloba (L.) Taub.). M.Sc. (Hort) Thesis, University of Horticultural Science, Bagalkot, Karnataka, India.

Mital, S.P. and Thomas, T.A. 1969. Correlation and Selection indices in improvement of seed yield in guar. Indian Journal of Agriculture Science. 40 (11): 1013-16.

Muthuselvi, R. and Shanthi, A. 2013. Variability, heritability and genetic advance in cluster bean (Cyamopsis tetragonoloba (L.) Taub.). Advance Research Journal of Crop Improvement. 4 (2): 106-09

Pathak, R, Singh, M. and Henry, A. 2009. Genetic divergence in cluster bean (Cyamopsis tetragonoloba (L.) Taub.) for seed yield and gum content under rainfed conditions. Indian Journal of Agricultural Sciences. 79 (7): 559-61.

Patil, D. V. 2014. Genetic variability and sowing dates effect of cluster bean (Cyamopsis tetragonoloba (L.) Taub.) genotypes in semi-arid region of Maharashtra, India. Plant Archives. 14(1):1-6.

Prakash, K. R., Parthsarthi, L. and Reddyshekhar, M. 2009. Studies on selection indices in Guar (Cyamopsis 
tetragonoloba (L.) Taub.). The Asian and Australian Journal of Plant Sciences and Biotechnology. 3(1): 2630.

Rai, N, Awasthi, B.S, Yadav, D.S. and Singh, A.K. 2004. Genetic analysis in French bean (Phaseolus vulgaris L.). Veg. Sci. 31(2): 138-141.

Rai, S. P, Dharmatti, P. R, Shashidhar, T. R, Patil, R. V. and Patil, B. R. 2012. Genetic variability studies in cluster bean (Cyamopsis tetragonoloba (L.) Taub.). Karnataka Journal of Agricultural Sciences. 25 (1): 108-11.

Revati, G, Srinivasa, V. and Lakshmana, D. 2017. Genetic variability and divergence studies in cluster bean (Cyamopsis tetragonoloba (L.) Taub.) Under hill zone of Karnataka, India. Legume Research. 40 (2): 237-40.

Sabarish, P. R. 2010. Genetic Variability studies in clusterbean (Cyamopsis tetragonoloba (L.) Taub) genotypes. $M$. Sc. Thesis, University of Agricultural Sciences, Dharwad, Karnataka.
Saini, D. D, Chaudhary, S. P. S, Singh, N. P, Singh, R. V. and Singh, J. 2004. Estimation of genetic parameters in clusterbean. National symposium on Arid Legumes for Sustainable Agriculture and trade. I-10: p6.

Saini, D. D, Singh, N. P, Chaudhary, S. P. S., Chaudhary, O. P. and Khedar, O. P. 2010. Genetic variability and association of component characters for seed yield in clusterbean [Cyamopsis tetragonoloba (L.) Taub. ]. Journal of Arid Legumes. 7(1): 47-51.

Singh, B.K, Singh, B.P. and Ram, H.H. 2000. Variability and correlation studies in bush type French bean (Phaseolus vulgaris L.) in relation to green pod yield. Progressive Horticulture. 32(2):176-182.

Singh, N. P, Choudhary, A. K. and Chaudhary, S. P. S. 2001. Variability and correlation studies in some genotypes of clusterbean. Advances in Arid Legume Research, Jodhpur. 2(1): 14-18.

\section{How to cite this article:}

Rishitha, G., R. Rajya Lakshmi, K. Uma Jyothi and Uma Krishna, K. 2019. Studies on Genetic Variability, Heritability and Genetic Advance for Yield and Yield Attributing Characters in Cluster Bean [Cyamopsis tetragonoloba (L.) Taub.]. Int.J.Curr.Microbiol.App.Sci. 8(08): 13071312. doi: https://doi.org/10.20546/ijcmas.2019.808.154 